\title{
Variations of bacterial community during the decomposition of Microcystis under different temperatures and biomass
}

\author{
Shuren Wang ${ }^{1,2+}$, Dayong Zhao ${ }^{1 \dagger}$, Jin Zeng ${ }^{2^{*}} \mathbb{D}$, Huimin $\mathrm{Xu}^{1}$, Rui Huang ${ }^{1}$, Congcong Jiao ${ }^{1}$ and Lin Guo ${ }^{3}$
}

\begin{abstract}
Background: The decomposition of Microcystis can dramatically change the physicochemical properties of freshwater ecosystems. Bacteria play an important role in decomposing organic matters and accelerating the cycling of materials within freshwater lakes. However, actions of the bacterial community are greatly influenced by temperature and the amount of organic matter available to decompose during a bloom. Therefore, it is vital to understand how different temperatures and biomass levels affect the bacterial community during the decomposition of Microcystis.

Results: Microcystis addition reduced the diversity of bacterial community. The composition of bacterial community differed markedly between samples with different biomass of Microcystis (no addition, low biomass addition: $0.17 \mathrm{~g} /$ $\mathrm{L}$, and high biomass addition: $0.33 \mathrm{~g} / \mathrm{L}$ ). In contrast, temperature factor did not contribute much to the different bacterial community composition. Total nitrogen (TN), total phosphorus (TP), total organic carbon (TOC), ammonia nitrogen $\left(\mathrm{NH}_{4}{ }^{+}-\mathrm{N}\right)$ and oxidation-reduction potential (ORP) were the key measured environmental variables shaping the composition of bacterial community.
\end{abstract}

Conclusions: Decomposition of Microcystis changed the physicochemical characteristics of the water and controlled the diversity and composition of the bacterial community. Microcystis biomass rather than temperature was the dominant factor affecting the diversity and composition of the bacterial community.

Keywords: Microcystis decomposition, Biomass, Temperature, Bacterial community

\section{Background}

With increased anthropogenic pressure within watersheds, eutrophication has become one of the most serious environmental problems facing Chinese freshwater lakes [1]. Microcystis blooms, affiliated to Cyanobacteria, are common in eutrophic freshwater lakes and harmful to human health $[2,3]$. Bacteria are a key component of aquatic ecosystems and play important roles in decomposing of organic matters derived from phytoplankton $[4,5]$. Bacterial communities associated with the growth of bloom-forming freshwater phytoplankton have received considerable attentions $[5,6]$. However, relatively

\footnotetext{
* Correspondence: jzeng@niglas.ac.cn

†'Shuren Wang and Dayong Zhao contributed equally to this work.

${ }^{2}$ State Key Laboratory of Lake Science and Environment, Nanjing Institute of Geography and Limnology, Chinese Academy of Sciences, 73 East Beijing

Road, Nanjing 210008, China

Full list of author information is available at the end of the article
}

few studies have assessed the response of freshwater bacterial communities to the decomposition of Microcystis. The bacteria-Microcystis relationship has important implications in aquatic ecosystems.

Previous studies have reported obvious changes in environmental variables as well as bacterial communities due to the decomposition of Microcystis [7-9]. The release of dissolved organic matter (DOM) by bloom-forming Microcystis is a ubiquitous process in eutrophic freshwater lakes [10]. The rapid depletion of dissolved oxygen was always associated with bloom decomposition [11]. Li et al. [7] observed spatial and temporal heterogeneity in the composition of both planktonic and particle-attached bacterial communities in an anoxic zone of Lake Taihu, the anoxia being caused by Microcystis decomposition. Zhao et al. [8] constructed microcosms to characterize the bacterial community composition in water and sediment during Microcystis decomposition and found that marked

(c) The Author(s). 2019 Open Access This article is distributed under the terms of the Creative Commons Attribution 4.0 International License (http://creativecommons.org/licenses/by/4.0/), which permits unrestricted use, distribution, and 
changes of dissolved organic carbon (DOC) and $\mathrm{pH}$ might be responsible for variations in bacterial communities. Temperature is an important factor driving the growth and metabolism of microorganisms. Xing et al. [9] simulated the degradation of Microcystis in anoxic water columns and found that temperature had a great influence on the bacterial community composition. Therefore, both temperature and Microcystis biomass are key factors influencing the microbial communities during Microcystis degradation.

Here, we took both Microcystis biomass and temperature into account to understand how the Microcystis decomposition affected the bacterial community. We constructed microcosms containing different amounts of Microcystis biomass and incubated under different temperatures. Water samples were collected at the time point of intense Microcystis decomposition. Water characteristics were examined and the 454 pyrosequencing was used to investigate the diversity and composition of the bacterial community in water samples. Our study aimed to (1) understand how Microcystis decomposition affected the diversity and composition of bacterial community; (2) determine whether temperature or Microcystis biomass was the dominant factor controlling freshwater bacterial communities during Microcystis decomposition.

\section{Results}

\section{Environmental variables during the decomposition of Microcystis}

Physicochemical properties in water samples of different treatments were shown in Fig. 1. Marked changes were observed for the treatments with highest Microcystis biomass addition ( $\mathrm{H}$ treatment). Overall, significant higher concentrations of TOC, TN, TP, $\mathrm{NH}_{4}{ }^{+}-\mathrm{N}$ and $\mathrm{NO}_{2}{ }^{-}$-N were observed in the treatments with Microcystis addition ( $\mathrm{H}$ and $\mathrm{L}$ treatments) compared with the control treatment (without Microcystis addition). The DO and ORP decreased significantly in high Microcystis biomass addition $(\mathrm{H})$ treatment. In contrast, little difference was found for the measured environmental variables between different temperature treatments $\left(15^{\circ} \mathrm{C}, 25^{\circ} \mathrm{C}\right.$, $35^{\circ} \mathrm{C}$ ) (Additional file 1: Figure S1).

\section{Diversity and composition of the bacterial community within the different treatments}

Two different diversity indices (Shannon-Wiener index and Faith's PD) were used to quantify the diversity of bacterial community of different treatments $\left(\mathrm{C}, \mathrm{L}, \mathrm{H} ; 15^{\circ} \mathrm{C}\right.$, $25^{\circ} \mathrm{C}, 35^{\circ} \mathrm{C}$ ). Both indices showed the same pattern. In Fig. 2a and b, significant decrease in the bacterial community of $\mathrm{H}$ treatment was found $(P<0.05)$, whereas no significant difference was observed in the bacterial community of the $\mathrm{C}$ and $\mathrm{L}$ treatments. In Fig. $2 \mathrm{c}$ and d, diversity of bacterial community did not differ significantly for different temperature treatments $(P>0.05)$.
Based on the Bray-Curtis and unweighted UniFrac distance, non-metric multidimensional scaling (NMDS) was performed to characterize the dissimilarity of bacterial community composition of the water samples. The bacterial community composition of the $\mathrm{C}, \mathrm{L}$ and $\mathrm{H}$ treatments were grouped into three distinct clusters based on the Bray-Curtis distance (Fig. 3a). However, the bacterial community composition of the $\mathrm{C}$ and $\mathrm{L}$ groups was not clearly separated based on the unweighted UniFrac distance (Fig. 3b). The dissimilarity of the bacterial community composition of the $\mathrm{H}$ treatment group $(0.66 \pm 0.03)$ was significant higher than those of the $C(0.62 \pm 0.03)$ and $\mathrm{L}(0.62 \pm 0.02)$ treatment groups $(P<0.05)$ (Fig. $3 \mathrm{c}$ ). The results of permutational multivariate analysis of variance (PERMANOVA) showed significant differences in the composition of the bacterial communities of the $\mathrm{C}$ and $\mathrm{H}(P<0.01)$ as well as the $\mathrm{L}$ and $\mathrm{H}$ groups $(P<0.01)$ (Table 1$)$. In contrast, temperature only maintained little effects on controlling the bacterial community composition (Table 1 ).

\section{Taxonomic features of bacterial communities during Microcystis decomposition}

The relative abundance at the phylum level calculated from the obtained bacterial sequences was presented in Additional file 2: Table S1. On average, Betaproteobacteria (52.98\%), Bacteroidetes (10.96\%), and Gammaproteobacteria $(9.34 \%)$ were the dominant phyla, followed by Alphaproteobacteria $(7.50 \%)$, Firmicutes $(7.23 \%)$, Actinobacteria (5.51\%), Planctomycetes (1.36\%), Parcubacteria (1.27\%) and Verrucomicrobia (1.09\%). Other phyla including Fusobacteria and Chloroflexi were found at low abundance $(<1 \%)$. Variations of the six dominant phyla were tested against different temperatures or Microcystis biomass additions (Additional file 3: Figure S2). The relative abundance of Firmicutes increased significantly with the addition of Microcystis biomass, however, decreased significantly with the elevated temperature $(P<0.05)$. Actinobacteria showed an opposite pattern. Variations of the relative abundance of the dominant phyla can be found in Additional file 4: Figure S3). The relative abundance of the top ten dominant genera in different treatments was shown in Fig. 4. The number of bacterial genera in the Microcystis-added treatments (especially the $\mathrm{H}$ group) was remarkably lower than that of the C group (Fig. 4). Several genera were depleted during the decomposition of Microcystis. However, temperature did not show any consistent effect on the number of bacterial genera among different biomass treatments.

\section{Relationships between environmental variables and bacterial community composition}

Mantel test was used to investigate the relationships between bacterial communities and the measured 

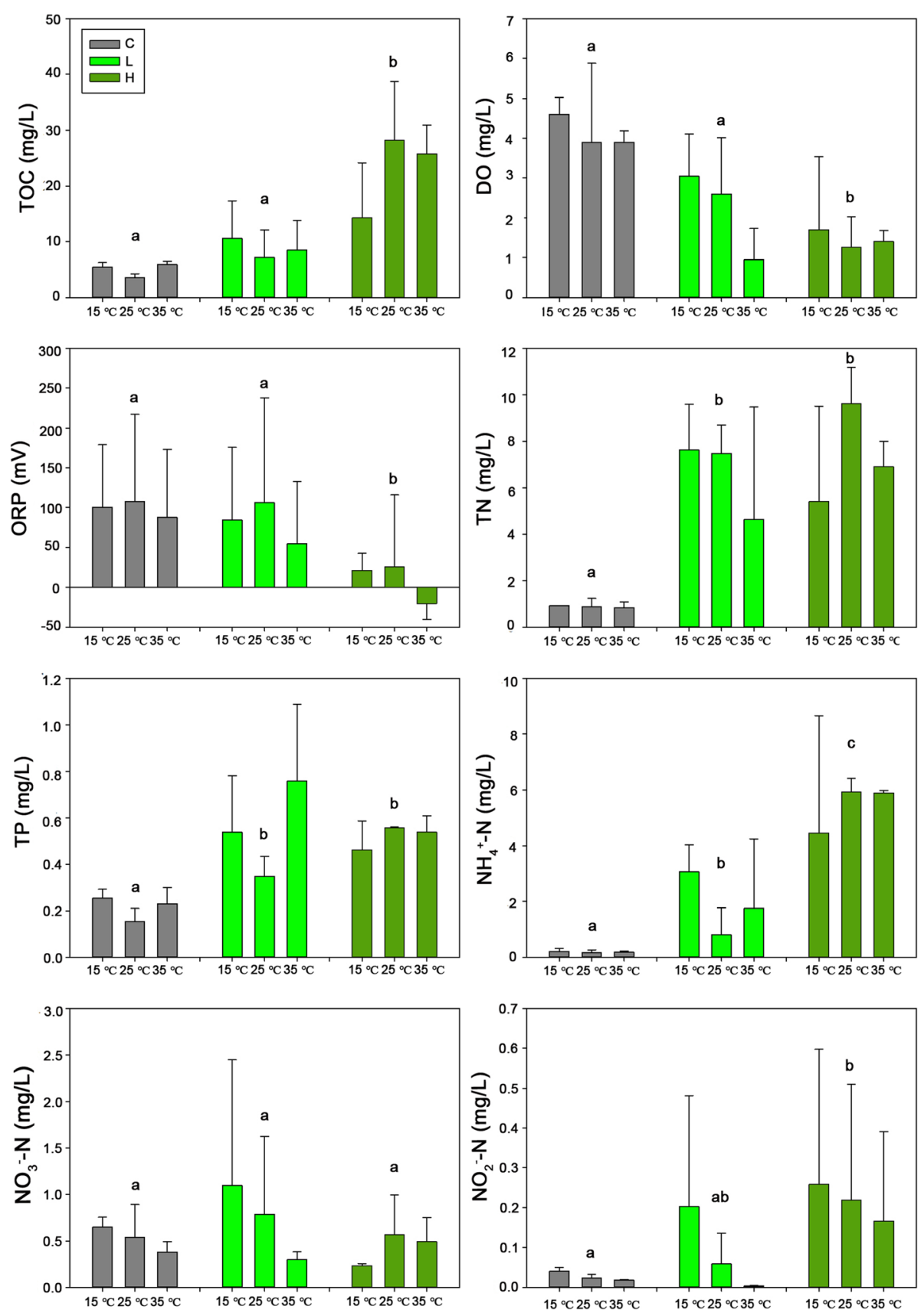

Fig. 1 Environmental variables of different Microcystis addition treatments. TOC, total organic carbon; DO, dissolved oxygen; ORP, oxidationreduction potential; $\mathrm{TN}$, total nitrogen; $\mathrm{TP}$, total phosphorus; $\mathrm{NH}_{4}{ }^{+}-\mathrm{N}$, ammonia nitrogen; $\mathrm{NO}_{3}{ }^{-} \mathrm{N}$, nitrate nitrogen; $\mathrm{NO}_{2}{ }^{-}-\mathrm{N}$, nitrite nitrogen. $\mathrm{C}$, without addition of Microcystis; L, low Microcystis biomass treatment; $\mathrm{H}$, high Microcystis biomass treatment. Different lowercase letters indicate significant difference (Duncan's multiple range test, $P<0.05$ )

environmental variables. Both OTU-based Bray-Curtis distance and phylogenetic tree-based unweighted UniFrac distance were taken into account. $\mathrm{NH}_{4}{ }^{+}-\mathrm{N}$ $(P<0.001)$, TOC $(P<0.001)$, ORP $(P<0.001)$ and TN $(P<0.05)$ were significantly correlated with both of the bacterial community distance matrices (Table 2).
In order to increase the robustness of the results, canonical correspondence analysis (CCA) was employed (Additional file 5: Figure S4). The two dominant axis totally explain $31.9 \%$ species-environment correlation. Community based on taxa abundance showed clustering characteristics with different Microcystis addition. TOC, 

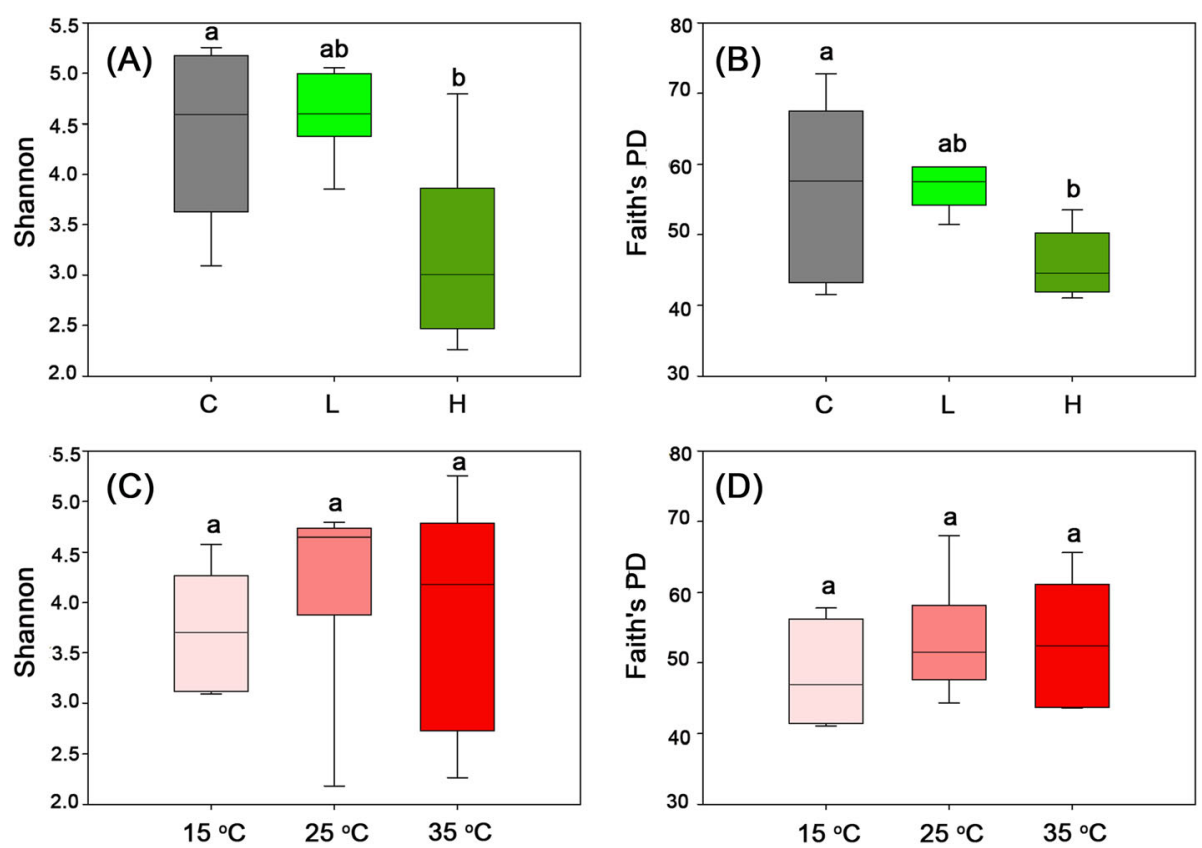

Fig. 2 Alpha diversity of bacterial communities from different treatments. $\mathbf{a}$, $\mathbf{b}$ : groups divided by Microcystis biomass; $\mathbf{c}$, d: groups divided by temperature. Shannon, Shannon-Weiner index; Faith's PD, the Faith's phylogenetic diversity. C, without addition of Microcystis; L, low Microcystis biomass treatment; H, High Microcystis biomass treatment. Different lowercase letters indicate significant difference (Duncan's multiple range test, $P<0.05$ )

DO and $\mathrm{NH}_{4}{ }^{+}-\mathrm{N}$ were the main environmental factors driving the community differentiation. According to the results of forward selection and ordination (Additional file 6: Table S2), ORP $(P<0.001), \mathrm{NH}_{4}^{+}-\mathrm{N}(P<0.01)$ and TOC $(P<0.05)$ were the most significant environmental factors driving the bacterial community composition.

\section{Discussion}

Decomposition of Microcystis modifies the diversity of bacterial community

Remarkable decreases in the diversity of bacterial community were observed for the Microcystis-addition treatments after 5-day incubation. The lowest diversity of bacterial community was observed in the $\mathrm{H}$ group (Fig. 2). Wang et al. [12] investigated the diversity of the bacterial community in nonylphenol-degrading sediments and found that the Shannon-Wiener index decreased with incubation time. The decomposition of Microcystis also reduced the diversity of bacterial community. However, Dilly et al. [13], investigating the bacterial community diversity in relation to the decomposition of crop residues, found a pattern of increased bacterial diversity with decomposition. The decreased diversity of our results in the $\mathrm{H}$ group was mainly due to the harsh environments (Low DO and ORP conditions) that favored the growth of specific bacterial groups [7], which could be a process of environmental filtering.

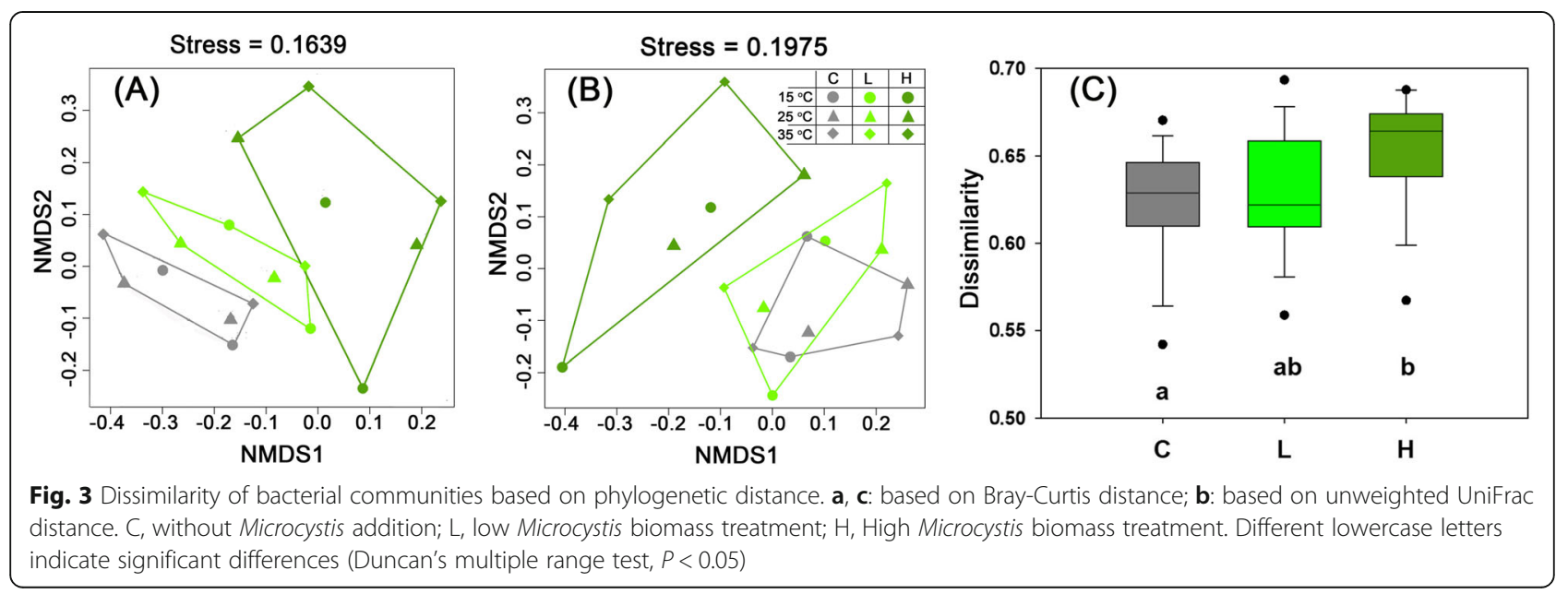


Table 1 Results of permutational multivariate analysis of variance (PERMANOVA) between different treatment groups

\begin{tabular}{clll}
\hline Groups 1 & $\mathrm{C}$ & $\mathrm{L}$ & $\mathrm{H}$ \\
$\mathrm{C}$ & - & $P=0.245$ & $P=0.003^{* *}$ \\
$\mathrm{~L}$ & $R^{2}=0.099$ & - & $P=0.005^{* *}$ \\
$\mathrm{H}$ & $R^{2}=0.198$ & $R^{2}=0.170$ & - \\
Groups 2 & $15^{\circ} \mathrm{C}$ & $25^{\circ} \mathrm{C}$ & $35^{\circ} \mathrm{C}$ \\
$15^{\circ} \mathrm{C}$ & - & $P=0.512$ & $P=0.185$ \\
$25^{\circ} \mathrm{C}$ & $R^{2}=0.088$ & - & $P=0.862$ \\
$35^{\circ} \mathrm{C}$ & $R^{2}=0.106$ & $R^{2}=0.066$ & - \\
\hline
\end{tabular}

Groups 1: groups divided by different Microcystis biomass; Groups 2: groups divided by different temperature. $C$, control treatment without addition of Microcystis; L, Low Microcystis biomass treatment; $\mathrm{H}$, High Microcystis biomass treatment. ${ }^{*} P<0.01$

The depletion of several bacterial genera in Microcystisadded groups in comparison with the control treatments also confirmed these results (Fig. 4).

Zhou et al. [14] indicated that nutrient additions could potentially weaken competition among different bacterial species and stimulate an increase in population growth. However, remarkable decreases in bacterial community diversity were observed in our experiments. The contradictory results could be attributed to the differences in the initial states of the two studies. The geochemical conditions in Zhou et al.'s study were relatively toxic to many organisms (low $\mathrm{pH}$ and high concentrations of nitrate, aluminum and other metals) and had a limited carbon source. However, the initial state of our study was not a harsh environment. In the present study, water was collected from a eutrophic lake (TN, $0.86 \mathrm{mg} /$ $\mathrm{L} ; \mathrm{TP}, 0.22 \mu \mathrm{g} / \mathrm{L}$; TOC, $5.92 \mathrm{mg} / \mathrm{L} ; \mathrm{DO}, 6.4 \mathrm{mg} / \mathrm{L} ; \mathrm{pH}$, 7.44; $\mathrm{NH}_{4}{ }^{+}-\mathrm{N}, 0.2 \mathrm{mg} / \mathrm{L} ;$ ORP, $51 \mathrm{mv}$ ). Therefore, the addition of Microcystis did not stimulate the growth of a variety of bacterial groups. However, the decomposition of large amounts of Microcystis biomass represented an extreme perturbation for the bacterial community. The consumption of the dissolved oxygen during decomposition produced an environmental stress for the bacterial community [11]. Moreover, toxins produced by Microcystis were released to the waters during its decomposition [15].

\section{Effects of Microcystis biomass and temperature on the bacterial community composition during the decomposition of Microcystis}

The clear separation among the $\mathrm{C}, \mathrm{L}$ and $\mathrm{H}$ groups (Fig. 3a) indicated that the addition of Microcystis affected the composition of the bacterial community (Fig. 3a). Meanwhile, higher dissimilarity of bacterial community was also observed in the $\mathrm{H}$ group (Fig. 3c). The scatter of the $\mathrm{H}$ group could be resulted from a divergence of species drove by the violent Microcystis decomposition compared with the other two groups. The pattern of phylogenetic-based beta diversity of bacterial community also highlighted the great effects of Microcystis decomposition of high biomass (Fig. 3b). Previous studies have verified the dynamic changes of bacterial community composition during Microcystis decomposition in freshwater lakes [16, 17]. Li et al. [7] reported strong relationships between the bacterial community composition and Microcystis decomposition, which were apparent along a gradient of Microcystis biomass. In lake sediments, the addition of Microcystis biomass (both $200 \mu \mathrm{g} / \mathrm{L}$ and $2000 \mu \mathrm{g} / \mathrm{L}$ ) also induced marked shifts in the composition of the bacterial community [16]. Here, we found the biomass of added Microcystis played more important roles than temperature in altering the composition of bacterial communities during the decomposition of Microcystis.

Some studies showed that bacterial community composition was related to the availability of organic matter, dissolved oxygen and $\mathrm{pH}[7,18]$. In our study, the rapid decay of Microcystis created an environment with a higher concentration of TN, TP, TOC and lower ORP and DO (Fig. 1). The results of the Mantel test demonstrated that TOC $(P<0.001)$, ORP $(P<0.001), \mathrm{NH}_{4}{ }^{+}-\mathrm{N}$ $(P<0.001)$ and TN $(P<0.05)$ were significant environmental variables in correlation with bacterial community composition (Table 2). Meanwhile, the result of CCA indicated that TOC, $\mathrm{NH}_{4}{ }^{+}-\mathrm{N}$ and DO were the key environmental factors driving the bacterial community composition (Additional file 5: Figure S4 and Additional file 6: Table S2). Previous studies have also found the correlations between DOC [19], TN [20], $\mathrm{NH}_{4}{ }^{+}-\mathrm{N}$ [20] and the composition or diversity of bacterial community.

Gucht et al. [21] found that Proteobacteria was the dominant phylum in freshwater ecosystems, the relative abundance of this phylum being very high in our samples, especially for Betaproteobacteria (Additional file 4: Figure S3). The relative abundance of Firmicutes increased significantly after the addition of Microcystis compared with the $\mathrm{C}$ group (Additional file 3: Figure S2). The genus Clostridium affiliated with Firmicutes was influenced strongly by the decomposition of Microcystis (Fig. 4). Previous study has observed that Clostridium was the dominant group (accounting for $72 \%$ of the sequenced clones) during Microcystis blooms [9]. Moreover, Zhao et al. [8] also found an increased abundance of Clostridium during the anaerobic decomposition of organic matter. Actinobacteria play an important role in the material cycle of freshwater ecosystems [22]. Although the decomposition of Microcystis provided a large amount of TOC, TN and TP, the process consumed much dissolved oxygen in the microcosm, which could partly explain the decreased relative abundance of some aerobic bacteria, such as Actinobacteria [23]. 


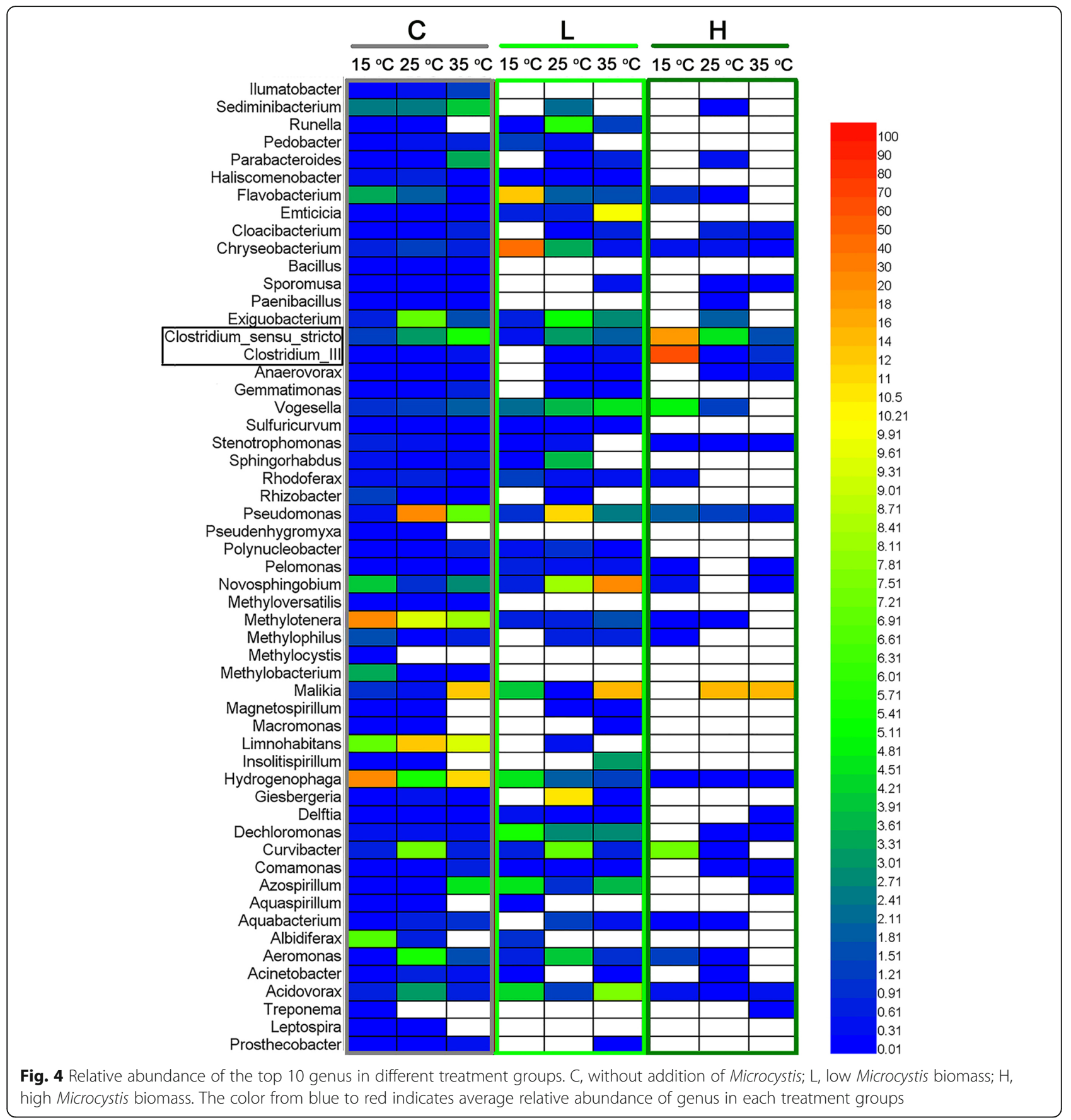

\section{Conclusions}

This study demonstrated that the biomass of added Microcystis was a key variable that shaped the composition and diversity of bacterial community in the microcosms, whereas temperature played little roles in driving the bacterial community composition. The intense decomposition of higher biomass of Microcystis reduced bacterial diversity. Clostridium affiliated to Firmicutes increased markedly during the process. TN, TP, TOC, $\mathrm{NH}_{4}{ }^{+}-\mathrm{N}$ and ORP were the dominant environmental factors correlated with bacterial community composition. The findings of the present study would be helpful for further understanding the impacts of cyanobacterial blooms on freshwater ecosystems.

\section{Methods}

Experimental design

Microcosms were built using sediments, lake water and Microcystis assemblages collected from Meiliang Bay

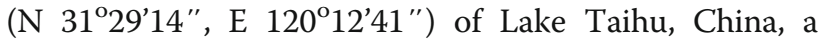


Table 2 Correlations as determined by Mantel tests between the bacterial community composition (Bray-Curtis and the unweighted UniFrac dissimilarity) and the measured environmental variables

\begin{tabular}{lll}
\hline Mantel test $\mathrm{R}$ & Bray-Curtis distance & Unifrac distance \\
\hline $\mathrm{NH}_{4}{ }^{+}-\mathrm{N}$ & $0.4025^{* * *}$ & $0.3844^{* *}$ \\
$\mathrm{TOC}$ & $0.3329^{* * *}$ & $0.4991^{* * *}$ \\
$\mathrm{ORP}$ & $0.3307^{* * *}$ & $0.5004^{* * *}$ \\
$\mathrm{TN}$ & $0.2233^{*}$ & $0.1687^{*}$ \\
$\mathrm{TP}$ & 0.0814 & 0.0327 \\
$\mathrm{DO}$ & 0.1781 & 0.0777 \\
$\mathrm{NO}_{2}{ }^{-}-\mathrm{N}$ & 0.0778 & -0.1874 \\
$\mathrm{NO}_{3}{ }^{-}{ }^{-\mathrm{N}}$ & 0.0154 & -0.1101
\end{tabular}

$\mathrm{NH}_{4}^{+}-\mathrm{N}$ Ammonia nitrogen, $\mathrm{TOC}$ Total organic carbon, ORP Oxidation-reduction potential, TN Total nitrogen, TP Total phosphorus, DO Dissolved oxygen, $\mathrm{NO}_{2}{ }^{-} \mathrm{N}$ Nitrite nitrogen, $\mathrm{NO}_{3}{ }^{-} \mathrm{N}$ Nitrate nitrogen. ${ }^{*} \mathrm{P}<0.05$ ${ }^{* *} P<0.01,{ }^{* * *} P<0.001$

large shallow eutrophic freshwater lake that suffering from serious Microcystis blooms every year in summer. Before microcosms constructed, the sediments were sieved (1-mm mesh) to remove macrofauna and large particles. Lake water was filtered with a plankton net to collect Microcystis colonies. The Microcystis colonies were then rinsed three times with ultrapure water before use. The Microcystis spp. constituted up to $97 \%$ of the total phytoplankton cells by using microscopic examination. The collected Microcystis colonies were frozen at $80{ }^{\circ} \mathrm{C}$ and then freeze-dried. The microcosms were built using plexiglas columns (diameter: $16 \mathrm{~cm}$; height: $30 \mathrm{~cm}$ ). The homogenized sediments and water were transferred into the columns and stabilize for 2 days under the designated temperature in an incubator. The results of our experiments indicated that the sterilization of Microcystis before biomass addition would not significantly affect the diversity and composition of bacterial community in water of the microcosms (Additional file 7: Methods and results of the supplementary experiments; Additional file 8: Figure S5; Additional file 9: Figure S6 and Additional file 10: Figure S7). The freeze-dried Microcystis colonies were added to the microcosms. Based on the Microcystis biomass in Lake Taihu reported in previous investigations [7, 8], three different Microcystis biomass treatments were designed: (1) the $\mathrm{H}$ treatment with a high Microcystis biomass addition $(\mathbf{H}, 0.33 \mathrm{~g} / \mathrm{L}),(2)$ the $\mathrm{L}$ treatment with a low Microcystis biomass addition $(\mathrm{L}, 0.17 \mathrm{~g} / \mathrm{L})$ and (3) the control treatment without Microcystis addition $(\mathrm{C}, 0 \mathrm{~g} / \mathrm{L})$. The microcosms were incubated under three different temperatures, 15,25 and $35^{\circ} \mathrm{C}$, to investigate the effects of temperature on the bacterial communities during decomposition process.

\section{Sampling and physicochemical analysis}

Referring to the results of previous studies [7, 8], marked variations in water properties were expected on days 2 to 5 after the addition of Microcystis, which signified violent decomposition. Therefore, samples were collected on day 5 for microbial community analysis. Water characteristics, including $\mathrm{pH}$, oxidation-reduction potential (ORP) and dissolved oxygen (DO) were analyzed with electrodes during incubation. Total nitrogen (TN) and total phosphorus (TP) were determined following Jin et al. [24]. The concentrations of ammonia nitrogen $\left(\mathrm{NH}_{4}{ }^{+}-\mathrm{N}\right)$, nitrate nitrogen $\left(\mathrm{NO}_{3}{ }^{-} \mathrm{-N}\right)$, nitrite nitrogen $\left(\mathrm{NO}_{2}{ }^{-}-\mathrm{N}\right)$ were measured by a continuous flow analyzer (San++, SKALAR, Netherlands) using the water samples collected after they passed through a $0.45 \mu \mathrm{m}$ pore-size filter. Bacteria were collected with a $0.22 \mu \mathrm{m}$ pore-size polycarbonate membrane filter (Millipore, Billerica, MA, USA). The filters were stored at $-80^{\circ} \mathrm{C}$ before further processing [25].

\section{DNA extraction, PCR and pyrosequencing}

We extracted bacterial genome DNA from each water sample using the E.Z.N.A. ${ }^{\circledR}$ Water DNA Kit (Omega Biotek, Doraville, GA) [26]. A nano-Drop ND-1000 spectrophotometer (NanoDrop Technologies, Wilmington, DE, USA) verified both the quality and quantity of the extracted DNA, and the extracted DNA was then amplified by PCR. The primers 533R (TTACCGCGGCTGCTGG CAC) and 8F (AGAGTTTGATCCTGGCTCAG), fixed with the Roche 454 sequencing adapters, were used to amplify the bacterial $16 \mathrm{~S}$ rRNA genes. Meanwhile, individual 10-bp barcode sequences of each sample were linked to the reverse primer 533R [27]. To reduce any error resulting from PCR amplification, three parallels were employed for each PCR reaction. The total volume of the PCR mixture was $20 \mu \mathrm{L}$, including $4 \mu \mathrm{L} 5 \times$ Prime STAR Buffer (plus $\mathrm{Mg}^{2+}$ ), 0.4 $\mu \mathrm{L}$ FastPfu DNA polymerase $(2.5 \mathrm{U} / \mu \mathrm{L}), 0.4 \mu \mathrm{L}$ for each of the forward and reverse primers $(5 \mu \mathrm{M}), 2 \mu \mathrm{L}$ dNTPs $(2.5 \mathrm{mM}), 10 \mathrm{ng}$ DNA template (about $10 \mathrm{ng} / \mu \mathrm{L}$ ). The thermal cycling conditions for PCR amplification followed the methods of Schloss et al. [28]. After being pooled, the PCR products were verified by gel electrophoresis, then purified using the AxyPrep DNA gel purification kit (Axygen Biotechnology Hangzhou Ltd., Hangzhou, China). After quantifying the purified PCR products, $>200 \mathrm{ng}$ DNA of each sample was sent to the Majorbio Company in Shanghai for pyrosequencing on a 454 FLX Titanium platform (Roche).

\section{Data processing and statistical analysis}

The DNA sequence data were trimmed and de-noised following the online 454 standard operating procedure (SOP) of the Mothur 1.39.0 software package [28, 29]. Sequences that were not fully matched with primers, having an average quality score $<27$ or containing any ambiguous reads, homopolymers $>8 \mathrm{nt}$ or sequences $<$ 
$200 \mathrm{bp}$ (excluding the barcode or primer) were removed from further analysis [30]. The remaining sequences were converted by reverse complementation and aligned against a bacterial SILV16S rRNA gene template (using NAST algorithm) [28]. Putative chimeric sequences and sequencing errors were removed by using the chimera.uchime and pre.cluster commands in Mothur [31]. The sequences were classified using a Bayesian classifier referring to the 16S rRNA gene training set of Ribosomal Database Project (http://rdp.cme.msu.edu) with the threshold of $80 \%$ [32]. Then, unknown sequences and sequences affiliated with Archaea, Cyanobacteria, chloroplast were excluded from further analysis.

Operational taxonomic units (OTUs) were clustered within the remaining sequences at a $3 \%$ dissimilarity [33]. The same number of sequences was drawn randomly from each dataset for estimating diversity at the same sequencing depth. The OTU richness was calculated by Shannon index $(H)$ according to the OTU table, while the phylogenetic diversity (PD) was estimated using Faith's index based on the phylogenetic tree [34, 35]. The command summary.single was used to calculate the Shannon index in Mothur [30]. The picante package [36] was used to estimate the Faith's PD [35] in R.

To determine the dissimilarity within bacterial community composition between any of the two sample pairs, we calculated the Bray-Curtis and unweighted UniFrac dissimilarity matrices [37]. Based on both of the matrices, non-metric multidimensional scaling (NMDS) was performed to estimate dissimilarities between water samples by using the vegan [38] and picante [36] packages in R. PERMANOVA (Adonis) was used to test the significance of patterns observed in NMDS. To demonstrate the relative abundance of the top ten genera in the different treatments, HemI software was used to generate the heatmap [39].

The function cca of vegan package was employed to explore the relationships between environmental variables and microbial community structure. The unimodal distribution pattern of bacterial communities along environmental gradient determined CCA (canonical correspondence analysis) rather than RDA (redundancy analysis) was the better method to explain the relationship. Environmental matrix and microbial community matrix were calculated by Euclidean distance and BrayCurtis dissimilarity distance, respectively [40]. The Mantel test, run with 999 permutations, was employed to determine the relationships between the dissimilarities of bacterial communities and the Euclidean distance matrix of measured environmental variables [41]. Dissimilarities of bacterial community composition were calculated based on both the Bray-Curtis distance and unweighted UniFrac distance. The Mantel test was run using the vegan package in $\mathrm{R}[42]$.

\section{Nucleotide sequence accession numbers}

The obtained raw data have been deposited in the NCBI short-reads archive database (Accession Number: SRP097674).

\section{Additional files}

Additional file 1: Figure S1. Comparision of environmental factors under different temperatures. TOC, total organic carbon; DO, dissolved oxygen; ORP, oxidation-reduction potential; TN, total nitrogen; TP, total phosphorus; $\mathrm{NH}_{4}{ }^{+}-\mathrm{N}$, ammonia nitrogen; $\mathrm{NO}_{3}{ }^{-} \mathrm{N}$, nitrate nitrogen; $\mathrm{NO}_{2}{ }^{-}$$\mathrm{N}$, nitrite nitrogen. $\mathrm{C}$, without addition of Microcystis; L, low Microcystis biomass treatment; $\mathrm{H}$, high Microcystis biomass treatment. The same lowercase letter represents there was no significant difference for the environmental factors under different temperatures. (TIF $4274 \mathrm{~kb}$ )

Additional file 2: Table S1. Relative abundance of the dominant bacterial phyla/subphyla in water samples of different treatment groups. (PDF $24 \mathrm{~kb}$ )

Additional file 3: Figure S2. Relative abundance of the six dominant bacterial phyla/subphyla in water samples of different treatment groups. (A) different Microcystis addition treatments; (B) different temperature treatments. C, without addition of Microcystis. L, low Microcystis biomass treatment; $\mathrm{H}$, High Microcystis biomass treatment. Significant differences between different treatment groups was indicated by asterisk (Duncan's multiple range test, $\left.{ }^{*} P<0.05\right)$. (TIF $3878 \mathrm{~kb}$ )

Additional file 4: Figure S3. Relative abundance of the dominant bacterial phyla/subphyla in water samples of different treatment groups. (A) Microcystis addition treatments, (B) different temperature treatments. C, without addition of Microcystis; L, low Microcystis biomass treatment; $H$, high Microcystis biomass treatment. (TIF 2026 kb)

Additional file $\mathbf{5}$ Figure S4. Canonical correspondence analysis (CCA) indicating the relationships between environmental variables and microbial community composition. Environmental matrix and microbial community matrix were calculated using the Euclidean distance and Bray-Curtis dissimilarity distance, respectively. Environmental variables were indicated with black arrows. C, without addition of Microcystis; L low Microcystis biomass treatment; $\mathrm{H}$, high Microcystis biomass treatment. (TIF 893 kb)

Additional file 6: Table S2. Results of the forward selection and ordination of canonical correspondence analysis (CCA). (PDF $73 \mathrm{~kb}$ )

Additional file 7: Methods and results of the supplementary experiments. (PDF 83 kb)

Additional file 8: Figure S5. Diversity of the bacterial communities derived from the Microcystis-sterilized and Microcystis-unsterilized groups (paired t-test). U, Microcystis-unsterilized groups; S, Microcystis-sterilized groups. Shannon, Shannon-Wiener index; PD, phylogenetic diversity. (TIF 47 kb)

Additional file 9 Figure S6. Non-metric multidimensional scaling (NMDS) of the bacterial communities based on (A) unweighted UniFrac dissimilarity matrix; (B) Bray-Curtis dissimilarity matrix. U, Microcystisunsterilized group; S, Microcystis-sterilized group. The values of $R^{2}$ and $P$ indicated the results of PERMANOVA. (TIF $1506 \mathrm{~kb}$ )

Additional file 10: Figure S7. Dissimilarity of bacterial communities within and between the Microcystis-sterilized (S) and Microcystisunsterilized (U) groups. (A) based on unweighted UniFrac dissimilarity matrix; (B) based on Bray-Curtis dissimilarity matrix. U, Microcystisunsterilized group; S, Microcystis-sterilized group. The same lowercase letter indicates no significant difference between groups (Duncan's multiple range test). (TIF $62 \mathrm{~kb}$ )

\section{Abbreviations}

DO: Dissolved oxygen; $\mathrm{H}$ : High Microcystis biomass treatment; L: Low Microcystis biomass treatment; $\mathrm{NH}_{4}{ }^{+}-\mathrm{N}$ : Ammonia nitrogen; $\mathrm{NO}_{2}{ }^{-} \mathrm{N}$ : Nitrite nitrogen. $\mathrm{C}$, without addition of Microcystis; $\mathrm{NO}_{3}-\mathrm{N}$ : Nitrate nitrogen; ORP: Oxidation-reduction potential; TN: Total nitrogen; TOC: Total organic carbon; TP: Total phosphorus 


\section{Acknowledgements}

The assistance of Xinyin Cao and Xiaowei He with data analysis and experiments are acknowledged.

\section{Authors' contributions}

SRW, DYZ, JZ and LG designed the experiments; SRW and RH performed the experiments; SRW, HMX, RH and CCJ analyzed the data; SRW, DYZ, JZ, HMX and LG wrote the manuscript; all authors read and approved the final manuscript.

\section{Funding}

This work was funded by the National Key R\&D Program of China (2016YFC0402710), the National Natural Science Foundation of China (31730013, 41621002, 41571108, 41671078 and 41871096), the National Key Technology R\&D Program (2015BAD13B01), the Key Research Program of Frontier Science, CAS (QYZDJ-SSW-DQC030), the Natural Science Foundation of Jiangsu Province (BK20181311), the Fundamental Research Funds for the Central Universities (2018B43414, 2019B17814), the Belt and Road Special Foundation of the State Key Laboratory of Hydrology-Water Resources and Hydraulic Engineering (2018490211) and the China Postdoctoral Science Foundation (2018M642147). The funders had no role in study design, data collection and analysis, interpretation of data, decision to publish, or preparation of the manuscript.

\section{Availability of data and materials}

The obtained raw data have been added to the NCBI short-reads archive database (Accession Number: SRP097674). Other data generated during the study are included in this manuscript and the additional files.

\section{Ethics approval and consent to participate}

Not applicable.

\section{Consent for publication}

Not applicable.

\section{Competing interests}

The authors declare that they have no competing interests.

\section{Author details}

${ }^{1}$ State Key Laboratory of Hydrology-Water Resources and Hydraulic Engineering, Joint International Research Laboratory of Global Change and Water Cycle, Hohai University, Xikang Road 1, Nanjing 210098, China. ${ }^{2}$ State Key Laboratory of Lake Science and Environment, Nanjing Institute of Geography and Limnology, Chinese Academy of Sciences, 73 East Beijing Road, Nanjing 210008, China. ${ }^{3}$ Department of Biological and Environmental Sciences, Texas A\&M University, Commerce, TX 76129, USA.

Received: 27 November 2018 Accepted: 28 August 2019

Published online: 04 September 2019

\section{References}

1. Guo L. Doing battle with the green monster of Taihu lake. Science. 2007; 317(5842):1166.

2. Chen M, Chen F, Xing P, Li HB, Wu QL. Microbial eukaryotic community in response to Microcystis spp. bloom, as assessed by an enclosure experiment in Lake Taihu, China. FEMS Microbiol Ecol. 2010;74(1):19-31.

3. Zhang Z, Zhang XX, Wu B, Yin J, Yu Y, Yang L. Comprehensive insights into microcystin-LR effects on hepatic lipid metabolism using cross-omics technologies. J Hazard Mater. 2016;315:126-34.

4. Buchan A, Lecleir GR, Gulvik CA, González JM. Master recyclers: features and functions of bacteria associated with phytoplankton blooms. Nat Rev Microbiol. 2014;12(10):686-98.

5. Eiler A, Bertilsson S. Comparison of freshwater bacterial communities associated with cyanobacterial blooms in four Swedish lakes. Environ Microbiol. 2010;6(12):1228-43

6. Parveen B, Ravet V, Djediat C, Mary I, Quiblier C, Debroas D. Bacterial communities associated with Microcystis colonies differ from free-living communities living in the same ecosystem. Environ Microbiol Rep. 2013; 5(5):716-24.
7. Li HB, Xing P, WU QL. Characterization of the bacterial community composition in a hypoxic zone induced by Microcystis blooms in Lake Taihu, China. FEMS Microbiol Ecol. 2012;79(3):773-84.

8. Zhao DY, Cao XY, Huang R, Zeng J, Wu QL. Variation of bacterial communities in water and sediments during the decomposition of Microcystis biomass. PLoS One. 2017;12(4):e0176397.

9. Xing P, Guo L, Tian W, Wu QL. Novel Clostridium populations involved in the anaerobic degradation of Microcystis blooms. ISME J. 2011;5(5):792-800.

10. Yang CH, Liu YZ, Zhu YX, Zhang Y. Microbial transformation of intracellular dissolved organic matter from Microcystis aeruginosa and its effect on the binding of pyrene under oxic and anoxic conditions. Environ Sci Pollut Res. 2017;24(7):6461-71.

11. De Figueiredo DR, Reboleira AS, Antunes SC, Abrantes N, Azeiteiro U, Goncalves F, Pereira MJ. The effect of environmental parameters and cyanobacterial blooms on phytoplankton dynamics of a Portuguese temperate lake. Hydrobiologia. 2006;568(1):145-57.

12. Wang SG, Diao XJ, He LS. Effects of algal bloom formation, outbreak, and extinction on heavy metal fractionation in the surficial sediments of Chaohu Lake. Environ Sci Pollut Res. 2015:22(18):14269-79.

13. Dilly $\mathrm{O}$, Bloem J, An V, Munch JC. Bacterial diversity in agricultural soils during litter decomposition. Appl Environ Microbiol. 2004;70(1):468-74.

14. Zhou JZ, Ye D, Zhang P, Xue K, Liang YT, Joy D, Yang YF, He ZL, Wu LY, David AS, Hazen TC, Tiedje JM, Arkin AP. Stochasticity, succession, and environmental perturbations in a fluidic ecosystem. Proc Natl Acad Sci. 2014;111(9):836-45.

15. Chorus I, Bartram J. Toxic cyanobacteria in water- a guide to their public health consequences, monitoring and management; 1999.

16. Shao K, Gao G, Chi K, Qin B, Tang X, Yao X, Dai J. Decomposition of Microcystis blooms: implications for the structure of the sediment bacterial community, as assessed by a mesocosm experiment in Lake Taihu, China. J Basic Microbiol. 2013;53(6):549-54.

17. Shao K, Zhang L, Wang Y, Yao X, Tang X, Qin B, Gao G. The responses of the taxa composition of particle-attached bacterial community to the decomposition of Microcystis blooms. Sci Total Environ. 2014:488-489(3):236-42.

18. Kolmonen E. Diversity of cyanobacteria and heterotrophic bacteria in cyanobacterial blooms in Lake Joutikas, Finland. Aquat Microb Ecol. 2004; 36(3):201-11.

19. Landa M, Blain S, Christaki U, Monchy S, Obernosterer I. Shifts in bacterial community composition associated with increased carbon cycling in a mosaic of phytoplankton blooms. ISME J. 2016;10(1):39-50.

20. Wu YF, Zheng H, Wu QL, Yang H, Liu SJ. Clostridium algifaecis sp. nov., an anaerobic bacterial species from decomposing algal scum. Int J Syst Evol Microbiol. 2014:64(11):3844-8.

21. Gucht KVD, Vandekerckhove T, Vloemans N, Cousin S, Muylaert K, Sabbe K, Gillis M, Declerk S, Meester LD, Vyverman W. Characterization of bacterial communities in four freshwater lakes differing in nutrient load and food web structure. FEMS Microbiol Ecol. 2005:53(2):205-20.

22. Elifantz H, Malmstrom RR, Cottrell MT. Assimilation of polysaccharides and glucose by major bacterial groups in the Delaware estuary. Appl Environ Microbiol. 2005;71(12):7799-805.

23. Schweitzer B, Huber I, Amann R. Alpha- and beta-Proteobacteria control the consumption and release of amino acids on lake snow aggregates. Appl Environ Microbiol. 2001:67(2):632-45.

24. Jin X, Wang S, Pang Y, Chang WF. Phosphorus fractions and the effect of $\mathrm{pH}$ on the phosphorus release of the sediments from different trophic areas in Taihu Lake, China. Environ Pollut. 2006;139(2):288-95.

25. Zhao DY, Xu HM, Zeng J. Community composition and assembly processes of the free-living and particle-attached bacteria in Taihu Lake. FEMS Microbiol Ecol. 2017;93(6):fix062.

26. Wu QL, Zwart G, Schauer M, Kamst-Van Agterveld MP, Hahn MW. Bacterioplankton community composition along a salinity gradient of sixteen highmountain lakes located on the Tibetan plateau, China. Appl Environ Microbiol. 2006;72(8):5548-485.

27. Huang $\mathrm{R}$, Zhao DY, Zeng J. pH affects bacterial community composition in soils across the Huashan watershed, China. Can J Microbiol. 2016;62(9):726-34.

28. Schloss PD, Gevers D, Westcott SL. Reducing the effects of PCR amplification and sequencing artifacts on $16 \mathrm{~S}$ rRNA-based studies. PLoS One. 2011:6(12):e27310.

29. Loman NJ, Misra RV, Dallman TJ, Constantinidou C, Gharbia SE, Wain J, Pallen MJ. Performance comparison of benchtop high-throughput sequencing platforms. Nat Biotechnol. 2012;30(5):434-9. 
30. Kunin V, Engelbrektson A, Ochman H, Hugenholtz P. Wrinkles in the rare biosphere: pyrosequencing errors can lead to artificial inflation of diversity estimates. Environ Microbiol. 2010;12(1):118-23.

31. Huse SM, Welch DM, Morrison HG, Sogin ML. Ironing out the wrinkles in the rare biosphere through improved OTU clustering. Environ Microbiol. 2010; 12(7):1889-98.

32. Wang Q, Garrity GM, Tiedje JM, Cole JR. Naive Bayesian classifier for rapid assignment of rRNA sequences into the new bacterial taxonomy. Appl Environ Microbiol. 2007;73(16):5261-7.

33. Schloss PD, Handelsman J. Introducing DOTUR, a computer program for defining operational taxonomic units and estimating species richness. Appl Environ Microbiol. 2005;71(3):1501-6.

34. Faith DP. Conservation evaluation and phylogenetic diversity. Biol Conserv. 1992;61(1):1-10

35. Hill TC, Walsh KA, Harris JA, Moffett BF. Using ecological diversity measures with bacterial communities. FEMS Microbiol Ecol. 2003;43(1):1-11.

36. Kembel SW, Cowan PD, Helmus MR, Cornwell WK, Morlon H, Ackerly DD, Blomberg SP, Webb CO. Picante: R tools for integrating phylogenies and ecology. Bioinformatics. 2010;26(11):1463-4.

37. Lozupone C, Hamady M, Knight R. UniFrac-An online tool for comparing microbial community diversity in a phylogenetic context. BMC Bioinf. 2006; 7(1):371.

38. Simpson GL, Solymos P, Stevens M, Wagner H. Vegan: community ecology package. Time Int. 2015;1997(6):15-7.

39. Deng W, Wang Y, Liu Z, Cheng H, Xue Y. Heml: a toolkit for illustrating heatmaps. PLoS One. 2014:9(11):e111988.

40. Huang R, Zhao D, Jiang CL. Heterogeneity of bacterial community compositions in surface sediments of three Lake zones in Lake Taihu. Proc Natl Acad Sci India B Biol Sci. 2015;85(2):465-74.

41. Zhao DY, Cao XY, Huang R. The heterogeneity of composition and assembly processes of the microbial community between different nutrient loading Lake zones in Taihu Lake. Appl Microbiol Biotechnol. 2017;101(14): 5913-23.

42. Oksanen J, Blanchet FG, Kindt R, Legendre P, Minchin PR, O'Hara RB. Vegan: community ecology package. R package vegan. 2015; vers. 2.2-1.

\section{Publisher's Note}

Springer Nature remains neutral with regard to jurisdictional claims in published maps and institutional affiliations.

Ready to submit your research? Choose BMC and benefit from:

- fast, convenient online submission

- thorough peer review by experienced researchers in your field

- rapid publication on acceptance

- support for research data, including large and complex data types

- gold Open Access which fosters wider collaboration and increased citations

- maximum visibility for your research: over $100 \mathrm{M}$ website views per year

At BMC, research is always in progress.

Learn more biomedcentral.com/submissions 